\title{
Use of cover crops in Oxisol and its effects on yield and soybean oil content
}

\section{Uso de plantas de cobertura em Latossolo argilloso e seus efeitos sobre a produtividade e teor de} óleo de soja

Uso de cultivos de cobertura en Oxisol y sus efectos sobre el rendimiento y el contenido de aceite de soja

Luciene Kazue Tokura ORCID: https://orcid.org/0000-0001-9758-0141 Universidade Estadual do Oeste do Paraná, Brasil

E-mail: lucienetokura@gmail.com

Deonir Secco

ORCID: https://orcid.org/0000-0002-3042-159X

Universidade Estadual do Oeste do Paraná, Brasil

E-mail: deonir.secco@unioeste.br

Luiz Antônio Zanão Júnior

ORCID: https://orcid.org/0000-0003-4159-1380 Instituto de Desenvolvimento Rural do Paraná, Brasil

E-mail: lazan10@ hotmail.com

Jair Antonio Cruz Siqueira

ORCID: https://orcid.org/0000-0002-8140-444X

Universidade Estadual do Oeste do Paraná, Brasil

E-mail: jair.siqueira@unioeste.br

Alessandra Mayumi Tokura Alovisi

ORCID: https://orcid.org/0000-0003-4236-4446

Universidade Federal da Grande Dourados, Brasil E-mail: alessandraalovisi@ufgd.edu.br

Andersson Barison

ORCID: https://orcid.org/0000-0001-9381-8239 Universidade Federal do Paraná, Brasil

E-mail: anderbarison@gmail.com

Willian Isao Tokura

ORCID: https://orcid.org/0000-0001-9363-793X Universidade Federal de Goiás, Brasil E-mail: willianisaotokura@hotmail.com

Bruna de Villa

ORCID: https://orcid.org/0000-0002-2401-7312

Universidade Estadual do Oeste do Paraná, Brasil E-mail: bruna.devilla.58@ hotmail.com

Lucas da Silveira

ORCID: https://orcid.org/0000-0001-7642-9485

Universidade Estadual do Oeste do Paraná, Brasil

E-mail: lucassbertolino@gmail.com

Francisco de Assis Guedes Junior ORCID: https://orcid.org/0000-0002-1870-9793

Universidade Estadual do Oeste do Paraná, Brasil

E-mail: franciscoguedes.chico@ hotmail.com

Simone Andreia Roehrs

ORCID: https://orcid.org/0000-0002-5677-0915

Universidade Estadual do Oeste do Paraná, Brasil E-mail: simone_roehrs@hotmail.com Luana Salete Celante

ORCID: https://orcid.org/0000-0002-6241-1193

Universidade Estadual do Oeste do Paraná, Brasil E-mail: luana_celante@ hotmail.com

Matheus Rodrigues Savioli

ORCID: https://orcid.org/0000-0001-8101-9149

Universidade Estadual do Oeste do Paraná, Brasil E-mail: matheus.savioli@unioeste.br

Zenaide Zin

ORCID: https://orcid.org/0000-0002-8958-6719

Universidade Estadual do Oeste do Paraná, Brasil

E-mail: zenaid_zin@hotmail.com 


\begin{abstract}
In the no-tillage system, soils generally exhibit some degree of compaction that limits agricultural production. In this scenario, the use of soil cover plants is one of the alternatives capable of improving the structural quality of the soil and increasing the productivity of crops, such as soybeans. In the context, the objective of this study was to evaluate the effect of plant cover species and management systems on the improvement of the physical characteristics of a Oxisol and its effects on the production and content of soybean oil. The treatments consisted of control, no-tillage system with gypsum, chiseling system, and 12 treatments with soil cover species composed of 6 summer species and 6 winter species, in completely randomized design. Soil samples were collected in the $0-0.1 ; 0.1-0.2$ and $0.2-0.3 \mathrm{~m}$ layers for determination of bulk density (BD), total porosity (TP), microporosity, macroporosity, and saturated soil hydraulic conductivity (Ksat) in 2014, 2017, 2018. Grain yield, oil content, thousand-seed weight, mean plant height and number of plants per meter were evaluated in soybean crop. Mean treatment values were compared by Tukey's test at 5\% significance. Five months after the chiseling system, there was no influence on BD. The treatments did not present differences six months after the application of gypsum. BD, TP, micro and macroporosity and Ksat were the variables most influenced by the periods of the year in the three soil layers. Grain yield, oil content, thousand-seed weight, plant height and number of plants per meter were influenced by the seasons.
\end{abstract}

Keywords: Soil physics; Oxisol; Soil cover; Oleaginous.

\title{
Resumo
}

No sistema de plantio direto, os solos geralmente apresentam algum grau de compactação que limita a produção agrícola. Nesse cenário, o uso de plantas de cobertura do solo é uma das alternativas capazes de melhorar a qualidade estrutural do solo e aumentar a produtividade das culturas, como a soja. Nesse contexto, o objetivo deste estudo foi avaliar o uso de espécies de cobertura vegetal e sistemas de manejo na melhoria das características físicas de um Latossolo argiloso e seus efeitos na produção e teor de óleo de soja. Os tratamentos consistiram na testemunha (controle), sistema plantio direto com gesso, sistema com escarificação e 12 tratamentos com espécies de cobertura do solo, sendo 6 espécies de verão e 6 de inverno, em delineamento inteiramente casualizado. As amostras de solo foram coletadas nas camadas: 0-0,1; 0,1-0,2 e 0,2-0,3 m, para determinação da densidade do solo (DS), porosidade total (TP), microporosidade, macroporosidade e condutividade hidráulica do solo saturado (Ksat) em 2014, $2017,2018$. Foram avaliados o rendimento de grãos de soja, teor de óleo, peso de 1000 sementes, altura média das plantas e número de plantas por metro. Os valores médios dos tratamentos foram comparados pelo teste de Tukey a 5\% de significância. Cinco meses após manejo do sistema com escarificação, não houve influência na DS. Os tratamentos não apresentaram diferenças significativas seis meses após a aplicação do gesso. DS, TP, micro e macroporosidade e Ksat foram as variáveis mais influenciadas pelos períodos do ano, nas três camadas de solo. A produtividade de grãos, teor de óleo, peso de 1000 sementes, altura das plantas e número de plantas por metro foram influenciados pelas estações do ano.

Palavras-chave: Física do solo; Latossolo argiloso; Culturas de cobertura do solo; Oleaginosas.

\section{Resumen}

En el sistema de labranza cero, los suelos suelen presentar algún grado de compactación que limita la producción agrícola. En este escenario, el uso de plantas de cobertura del suelo es una de las alternativas capaces de mejorar la calidad estructural del suelo y aumentar la productividad de los cultivos, como la soja. En ese contexto, el objetivo de este estudio fue evaluar el uso de especies de cobertura vegetal y sistemas de manejo en la mejora de las características físicas de un Latoso arcilloso y sus efectos en la producción y contenido de aceite de soja. Los tratamientos consistieron en el testigo (control), sistema labranza cero con yeso, sistema con escarificación y 12 tratamientos con especies de cobertura del suelo, siendo 6 especies de verano y 6 de invierno, en delineamiento enteramente casualizado. Las muestras de suelo se recogieron en las capas: 0-0,1; 0,1-0,2 y 0,2-0,3 m, para la determinación de la densidad del suelo (DS), porosidad total (TP), microporosidad, macroporosidad y conductividad hidráulica del suelo saturado (Ksat) en 2014, 2017, 2018. Se evaluaron el rendimiento de la soja, el contenido de aceite, el peso de 1000 semillas, la altura media de las plantas y el número de plantas por metro. Los valores medios de los tratamientos fueron comparados por la prueba de Tukey al 5\% de significancia. Cinco meses después del manejo del sistema con escarificación, no hubo influencia en la DS. Los tratamientos no mostraron diferencias significativas seis meses después de la aplicación del yeso. DS, TP, micro y macroporosidad y Ksat fueron las variables más influenciadas por los períodos del año, en las tres capas de suelo. La productividad de los granos, el contenido de aceite, el peso de 1000 semillas, la altura de las plantas y el número de plantas por metro fueron influenciados por las estaciones del año.

Palabras clave: Física del suelo; Latoso arcilloso; Cultivos de cobertura del suelo; Semillas oleaginosas.

\section{Introduction}

Soil is a medium in which plants obtain all the materials necessary for their development. Thus, it is necessary to develop sustainable agricultural practices to preserve its physical and chemical properties and ensure more stable yields over 
time. Among the types of sustainable management, no-tillage system is a unique system, which maintains the vegetal remains of other crops on the surface and allows the minimum mobilization to the constituents of the soil (Caires et al., 2006).

In this agricultural system the continuous maintenance of the soil cover on the surface, confer positive changes in the soil structure (Blanco-Canqui et al., 2013; Giarola et al., 2013; Rabot et al., 2018) and in the yield of the crops in succession (Adetunji et al., 2020).

In spite of the large number of studies addressing the positive aspects of no-tillage system, when this system is managed inadequately without considering the moisture conditions in which field operations are performed, it has led the soil to compaction (Saffih-Hidadi et al., 2009; Giarola et al., 2013; Nawaz, et al., 2013; Jia et al., 2017; Ilek et al., 2017; Shan et al., 2019). Secco et al. (2009) also point out that in addition to the soil moisture conditions, it is also important to consider the time of use of the different management systems, textural class, and crop rotation systems used.

Compacted soils alter physical and chemical properties, causing an increase in bulk density and reduction in porosity, consequently influencing the availability of water to the plants (Silva et al., 2003; Richert et al., 2007; Silva et al., 2014), especially in soils more susceptible to this compaction, such as the class of Latosols (Mazurana et al., 2017).

One of the strategies to decompress or delay the increase in compaction has been through mechanical chiseling system (Drescher et al., 2016). Although this mechanized operation breaks up the compacted layers, the maintenance of beneficial effects on soil properties lasts for a short time and new compaction takes place (Tormena et al., 2002). However, authors like Drescher et al. (2011) have reported that the persistence of the chiseling system effect can extend for more than 2 years.

An alternative to promote soil decompression has been the use of cover species with deep roots capable of growing in high-resistance soils. These roots create channels that facilitate the recycling and release of nutrients for the development of rotating crops. In addition to the greater presence of macropores, improving hydraulic conductivity and water retention in the soil (Balesdent et al., 2000; Blanco-Canqui et al., 2013; Blanco-Canqui et al., 2015; Rabot et al., 2018; Gimenez et al., 2021).

Thus, studies with decompacting species of the summer and winter cycles in different soil management systems are necessary to ensure a diversity of species that are capable of producing different amounts of plant residues that, when decomposing, may positively alter soil physical and chemical attributes and, subsequently, the productive characteristics of the successor crop. Thus, the purpose of this study was to evaluate the effect of management systems and plant cover species on soil structure and their effects on the soybean crop.

\section{Methodology}

\subsection{Location and characteristics of the experiment}

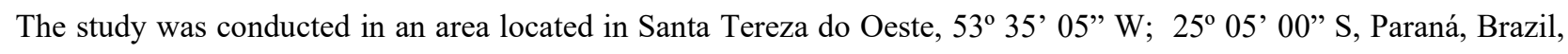
and altitude of $756 \mathrm{~m}$ (Figure 1). 
Figure 1. Aerial image of the 15 plots.

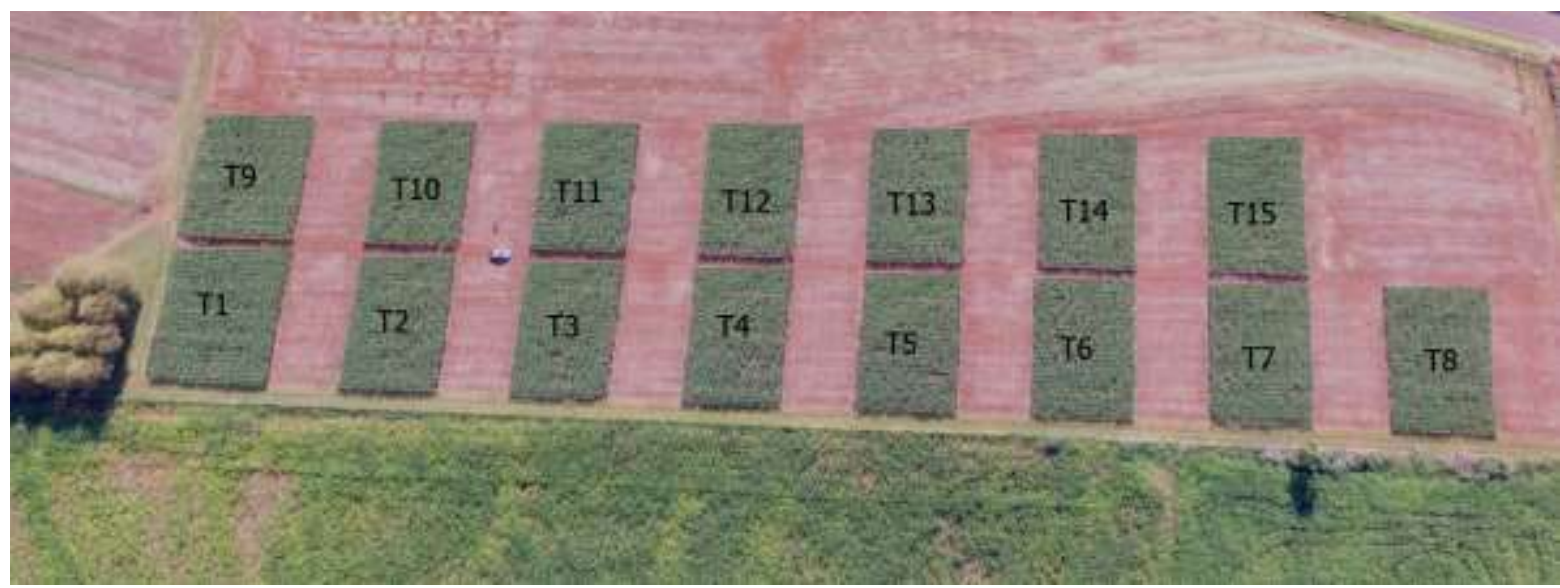

Source: Authors.

Humid subtropical climate (Cfa - Köppen classification) (Peel et al., 2007) and 1,800 mm precipitation. The soil was classified as an Oxisol (Soil Survey Staff, 2014), with a particle size of $636.4 \mathrm{~g} \mathrm{~kg}^{-1}$ clay, $36.1 \mathrm{~g} \mathrm{~kg}^{-1}$ sand and $327.5 \mathrm{~g} \mathrm{~kg}^{-1}$ silt.

\subsection{Area weather data}

Rainfall and temperature data (maximum and minimum) obtained in the experimental period were obtained by a pluviometer (Figure 2).

Figure 2. Monthly rainfall (historical mean and the experimental period), minimum, maximum, and mean temperatures from October 2016 to March 2017 (A) and October 2017 to February 2018 (B).

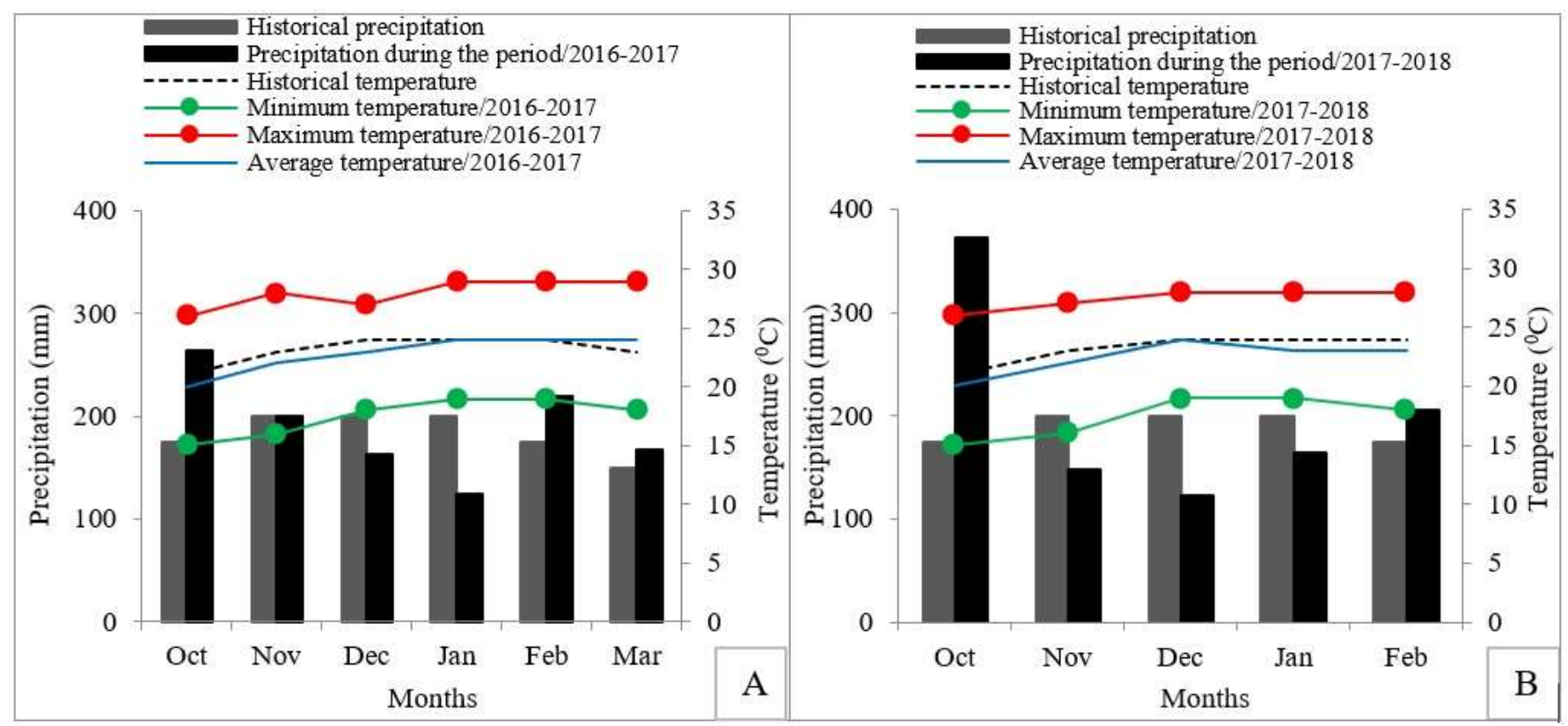

Source: Authors.

\subsection{Soil profile}

To determine soil characteristics, undeformed samples were taken before the implementation of the experiment and after the commercial crop. The samples were taken at the depths from 0-0.1;0.1-0.2;0.2-0.3 m, with 4 replicates for the determination of bulk density (BD) (Equation 1), total porosity (TP) (Equation 2), microporosity (Micro) (Equation 3) (Reinert 
\& Reichert, 2006), macroporosity (Macro) (Equation 4), and saturated soil hydraulic conductivity (Ksat) by the constant head permeameter method (Equation 5) were evaluated.

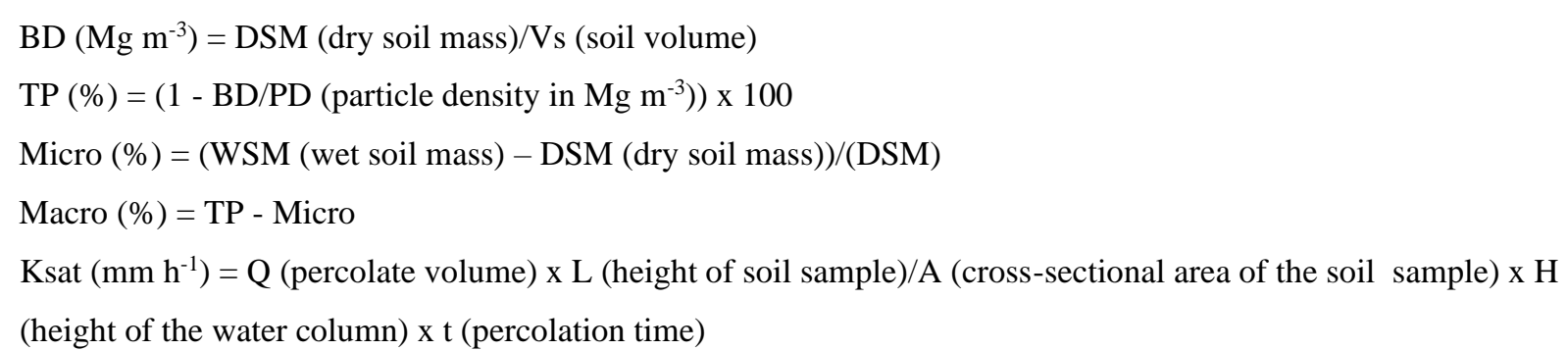

The experiment began in March 2014 in an area with a 20-year history under a no-tillage system.

The present study covered the period from March 2016 to February 2018, with the implantation of cover species (summer and winter), succeeded by soybean (2016/17 and 2017/18 crops).

\subsection{Description and design of treatments}

The experimental design was completely randomized with 15 treatments, with each area represented by the dimensions of $20 \mathrm{~m}$ in length and $25 \mathrm{~m}$ in width. Twelve treatments were implemented with plant cover species (six summer species and six winter species) and three plots in no-tillage system: with gypsum, with chiseling, and control, the latter being the control. The treatments cultivated with summer cover species were pearl millet (Pennisetum americanum), dwarf pigeon pea (Cajanus cajan), sunn hemp (Crotalaria juncea), pigeon pea (Cajanus cajan), showy rattlebox (Crotalaria spectabilis) and velvet bean (Mucuna pruriens). The winter plant cover species were common oat (Avena sativa), black oat (Avena strigosa), cereal rye (Secale cereale), black oat + cultivated radish (Raphanus sativus), black oat + white lupin (Lupinus albus), and black oat + garden pea (Pisum arvense). The summer and winter cover species were sown without fertilization.

The desiccation of the summer and winter plant cover species occurred at the time of flowering with application of original Roundup ( $4 \mathrm{~L} \mathrm{ha}^{-1}$ ). Following that, Triton was used so that the plant residues could be evenly distributed in the area.

The mechanical chiseling treatment was carried out on October 06, 2017, at a depth of up to $0.30 \mathrm{~m}$ using a tractor equipped with Kohler chisel with five adjustable rods with a spacing of $0.50 \mathrm{~m}$. The system with gypsum application was performed on November 11, 2017, with application of $3 \mathrm{Mg} \mathrm{ha}^{-1}$ on the surface of the experimental plot. The last lime application in the area was performed on September 20, 2017, with $3 \mathrm{Mg} \mathrm{ha}^{-1}$ of limestone.

\subsection{Sowing and harvesting of soybeans}

Sowing of the soybean (Glycine max (L.) Merrill) was carried out on October 07, 2016 (Figure 3), and November 10, 2017 (Figure 4), throughout the experimental area, on the plant remains of the soil cover species. The cultivars used were NA5909 RG (2016/17 crop) and Lança IPRO (2017/18 crop), respectively, with a spacing of 0.45 m between rows, 15 seeds per meter, and fertilization of $300 \mathrm{~kg} \mathrm{ha}^{-1}$ of the formula NPK 2-20-18. 
Research, Society and Development, v. 10, n. 12, e353101220514, 2021

(CC BY 4.0) | ISSN 2525-3409 | DOI: http://dx.doi.org/10.33448/rsd-v10i12.20514

Figure 3. Sowing 10/07/16 (A), 13 days after sowing (DAS) (B), 27 DAS (C), 34 DAS (D), 49 DAS (E), 62 DAS (F), 97 DAS (G), 108 DAS (H), 137 DAS (I) and 03/08/17 harvest (J).

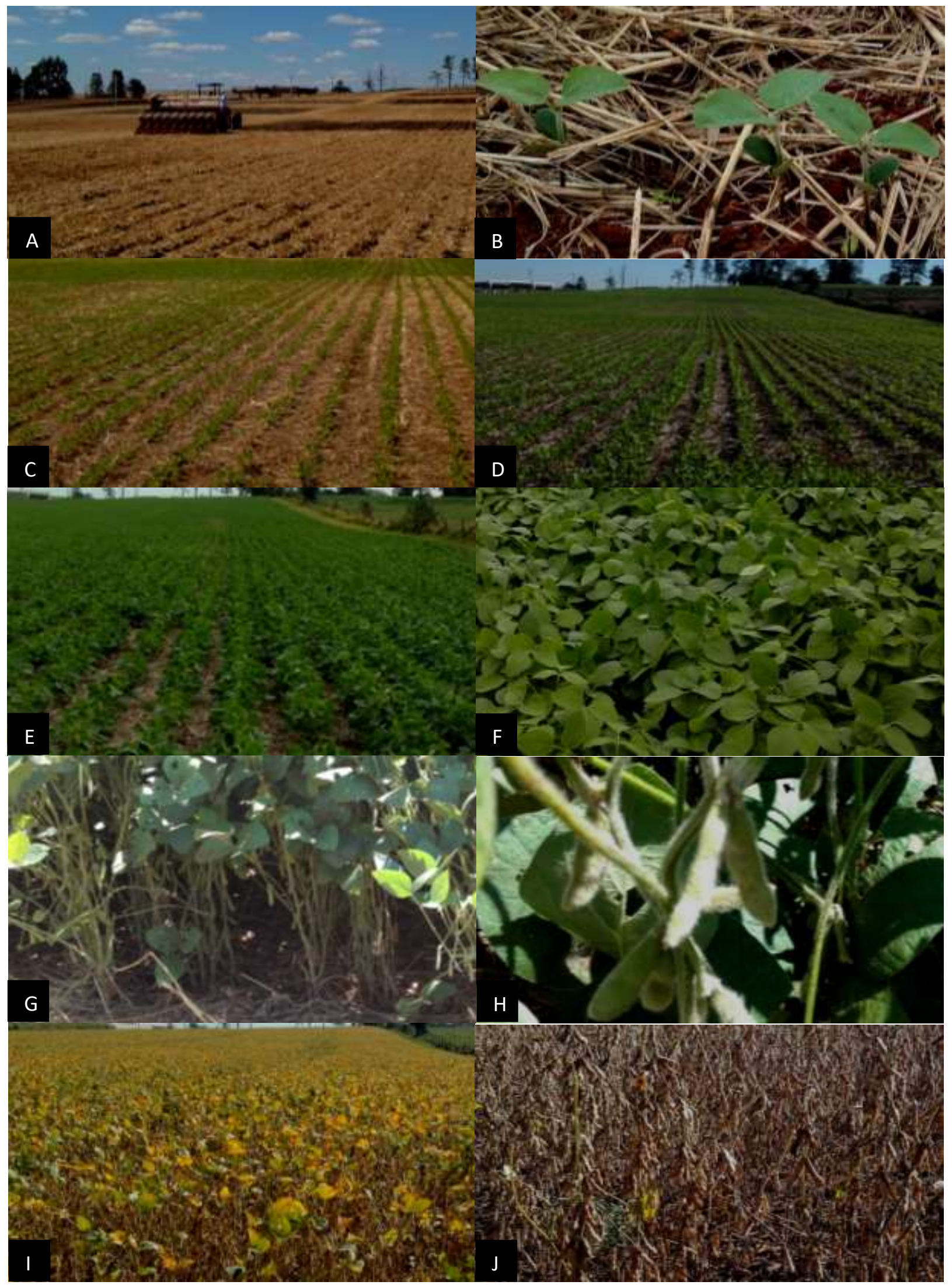

Source: Authors. 
Research, Society and Development, v. 10, n. 12, e353101220514, 2021

(CC BY 4.0) | ISSN 2525-3409 | DOI: http://dx.doi.org/10.33448/rsd-v10i12.20514

Figure 4. Sowing 10/11/17 (A), 13 days after sowing (DAS) (B), 27 DAS (C), 41 DAS (D), 58 DAS (E), 71 DAS (F), 76 DAS (G), 110 DAS (H), 128 DAS (I) and 02/26/18 harvest (J).

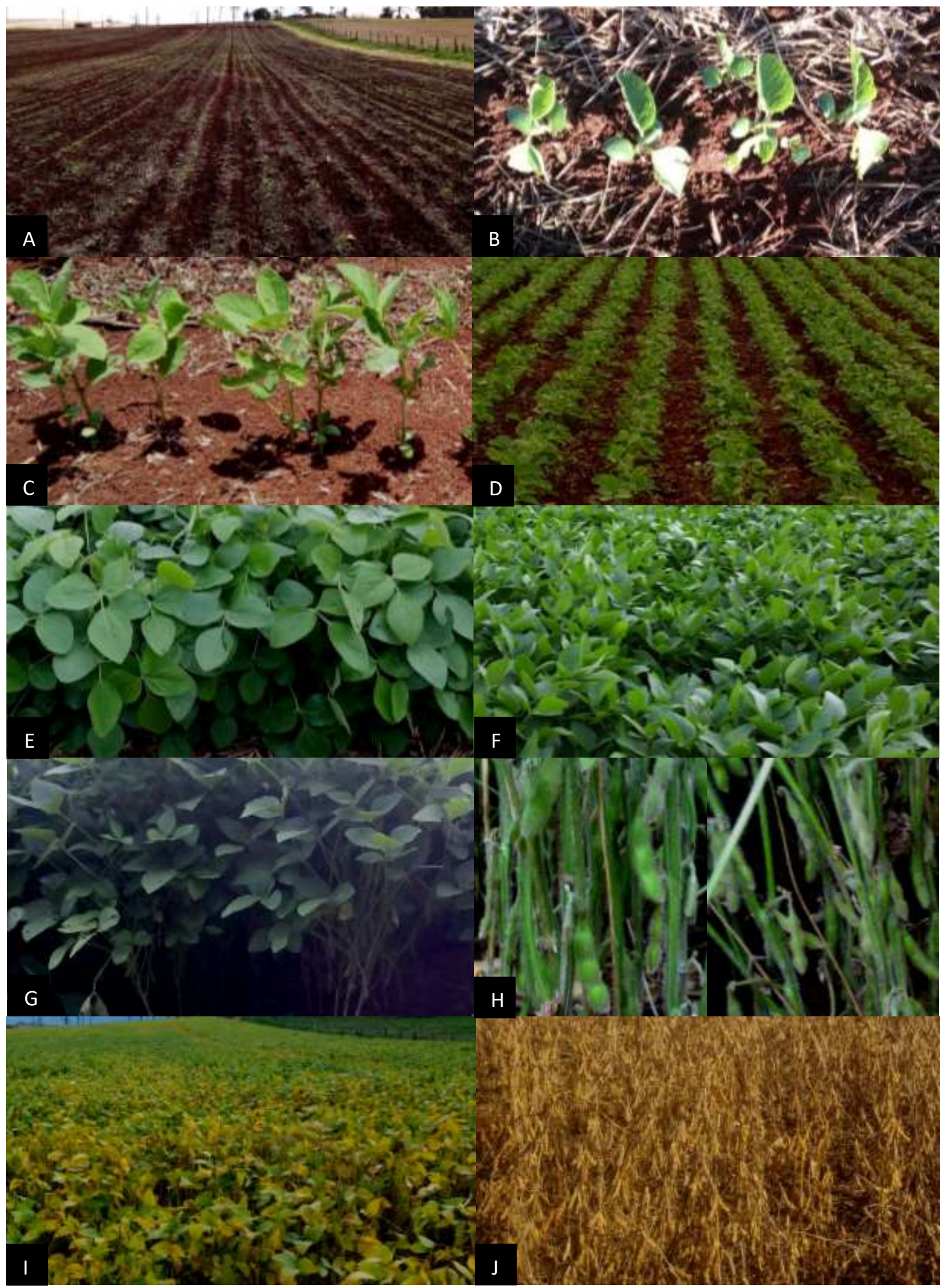

Source: Authors. 
The crop practices for the control of weeds, pests and diseases were carried out in the experimental area, according to technical recommendations for the soybean crop.

The soybean harvest was carried out using a Wintersteiger Classic plot harvester, on March 08, 2017 (2016/17 crop) and February 26, 2018 (2017/18 crop). Grain yield was evaluated in central areas of $8.1 \mathrm{~m}^{2}$, consisting of 3 rows of $6.0 \mathrm{~m}$, with a spacing of $0.45 \mathrm{~m}$ between rows, with four replicates per plot. The material harvested from each plot was placed in properly identified paper bags, after which the impurities were removed, and the seeds were cleaned and weighed in a semi-analytical balance. The determination of soil physical characteristics (SD, TP, Micro, Macro, and Ksat) was carried out at the Soil Physics Laboratory (LAFIS) of the State University of Western Paraná, in Cascavel, PR, Brazil.

The yield of the soybean grains was obtained from the weight of each subplot and conversion into $\mathrm{kg} \mathrm{ha}^{-1}$, with moisture correction to $13 \%$.

\subsection{Statistical analysis}

With the obtaining of the data, the statistical analyses were carried out using the computer program Sistema para Análise de Variância (Sisvar ${ }^{\circledR}$ - Statistic Analysis Software, Lavras, MG, Brazil) (Ferreira, 2011). The mean values of the studied variables were compared by the Tukey test, at $5 \%$ probability.

\section{Results and Discussion}

\subsection{Physical soil analysis}

The values of bulk density (BD), total porosity (TP), microporosity (Micro), macroporosity (Macro) and saturated soil hydraulic conductivity (Ksat) of the plant cover species and management systems are presented in Figures 5, 6 and 7. The physical characteristics were evaluated at the initial characterization (2014) of soil and after the soybean harvest (2017 and 2018), in the 0-0.1; 0.1-0.2 and 0.2-0.3 m layers, respectively.

In Figure 5, it was observed that the physical characteristics evaluated in the 0-0.1 m layer presented significant differences between the treatments and the evaluated periods for bulk density, total porosity, microporosity and Ksat on CO coverage.

As the soil surface layer is more susceptible to the mobilization of seed drill mechanisms for each crop, the occurrence of significant differences between the treatments and periods evaluated in this layer can be attributed to the use and management of this soil.

Among the periods and treatments, CO coverage in 2018 presented the smallest significant differences between BD, TP, Micro and Ksat.

This information is in line with the results found by Balesdent et al. (2000) and Tormena et al. (2002), who report that soil management provides a periodic rupture of the soil structure, altering the physical properties of the soil. Mesquita and Moraes (2004) also state that, because of the soil management in superficial layers, there is usually a greater variation in BD, which may lead to the formation of pores of larger diameters, thereby allowing higher Ksat values. These pores, however, may not influence BD values. 
Figure 5. Mean values of bulk density (A), total porosity (B), microporosity (C), macroporosity (D) and saturated soil hydraulic conductivity $(\mathrm{E})$ in treatments with 12 plant cover species and three management systems, in the $0-0.1 \mathrm{~m}$ layer. $\mathrm{PM}=$ pearl millet; $\mathrm{DPP}=$ dwarf pigeon pea; $\mathrm{SH}=$ sunn hemp; $\mathrm{PP}=$ pigeon pea; $\mathrm{SR}=$ showy rattlebox; $\mathrm{VB}=$ velvet bean; $\mathrm{CO}=$ common oat; $\mathrm{BO}=$ black oat; $\mathrm{CR}=$ cereal rye; $\mathrm{BO}+\mathrm{CUR}=$ black oat + cultivated radish; $\mathrm{BO}+\mathrm{WL}=$ black oat + white lupine; $\mathrm{BO}+\mathrm{GP}=$ black oat + garden pea; CS: chiseling system; NTSG: no-tillage system with gypsum; NTS: no-tillage system (control). The mean value is indicated by + when significant differences occurred between the periods and indicated by $*$ when significant differences occurred between the treatments by the Tukey test, at $5 \%$ significance $(* \mathrm{P}<0.05)$.
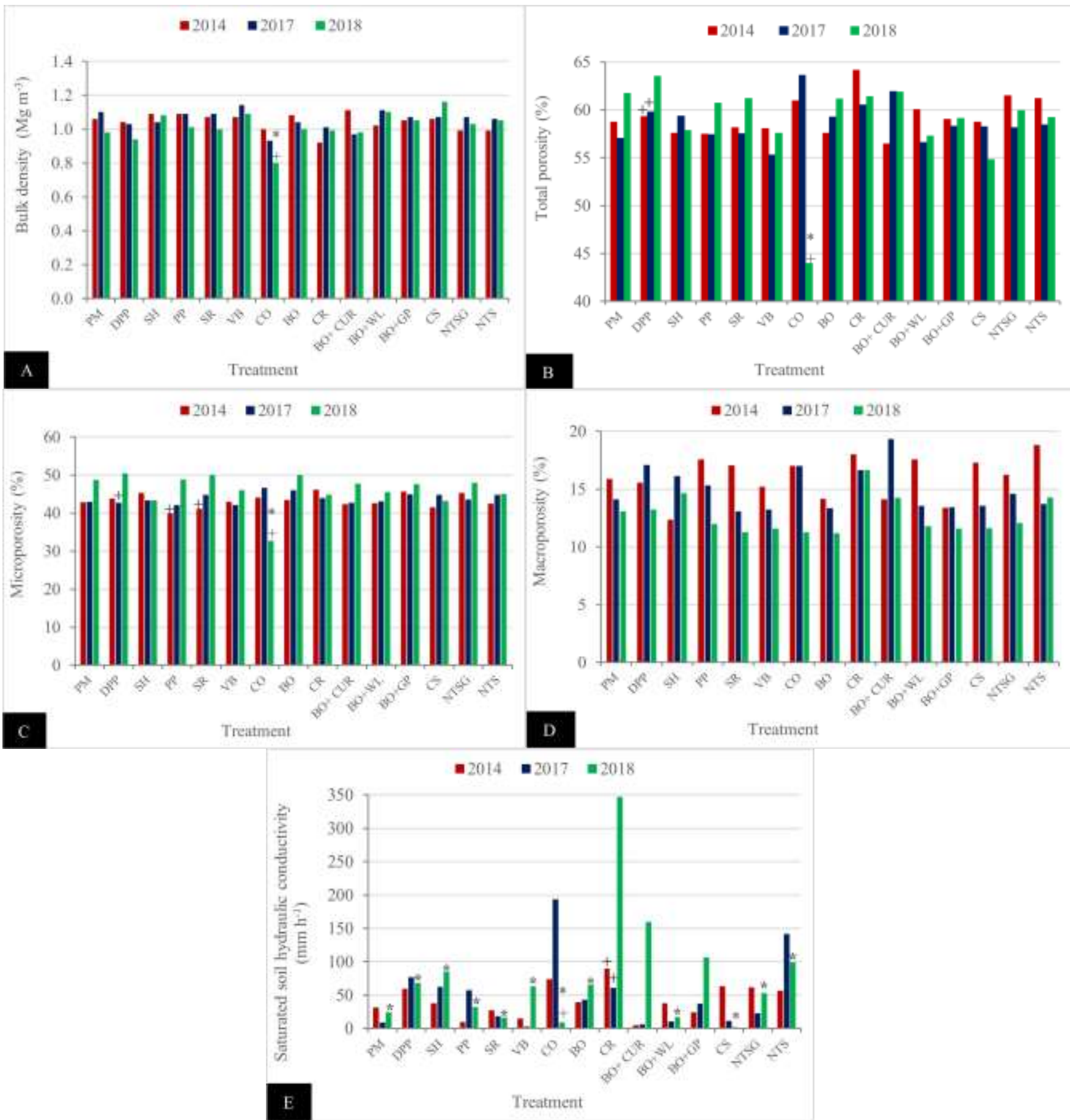

Source: Authors. 
Figure 6. Mean values of bulk density (A), total porosity (B), microporosity (C), macroporosity (D) and saturated soil hydraulic conductivity (E) in treatments with 12 plant cover species and three management systems, in the $0.1-0.2 \mathrm{~m}$ layer. PM = pearl millet; $\mathrm{DPP}=$ dwarf pigeon pea; $\mathrm{SH}=$ sunn hemp; $\mathrm{PP}=$ pigeon pea; $\mathrm{SR}=$ showy rattlebox; $\mathrm{VB}=\mathrm{velvet}$ bean; $\mathrm{CO}=$ common oat; $\mathrm{BO}=$ black oat; $\mathrm{CR}=$ Cereal Rye; $\mathrm{BO}+\mathrm{CUR}=$ black oat + cultivated radish; $\mathrm{BO}+\mathrm{WL}=$ black oat + white lupine; BO+GP = black oat + garden pea; CS: chiseling system; NTSG: no-tillage system with gypsum; NTS: no-tillage system (control). The mean value is indicated by + when significant differences occurred between the periods and indicated by $*$ when significant differences occurred between the treatments by the Tukey test, at $5 \%$ significance $(* \mathrm{P}<0.05)$.
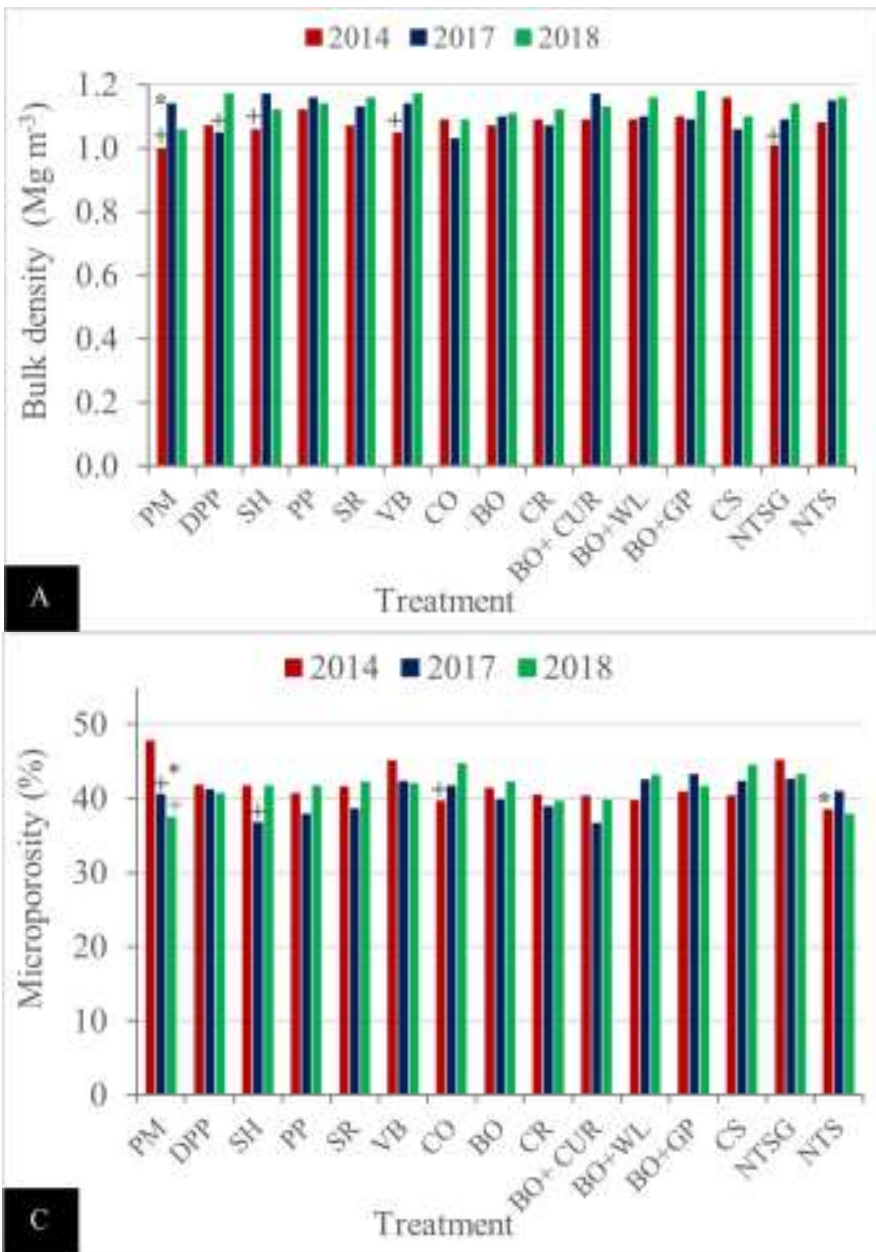
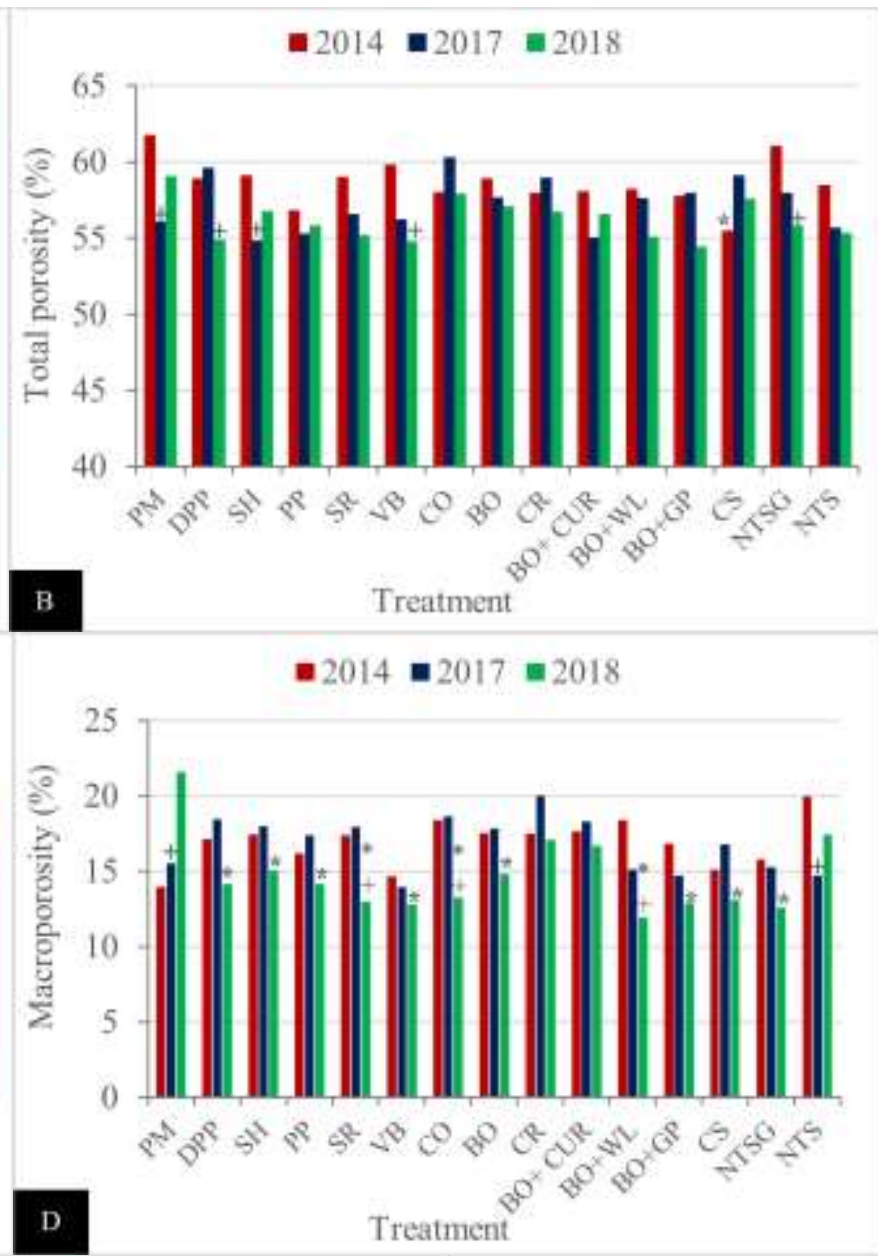

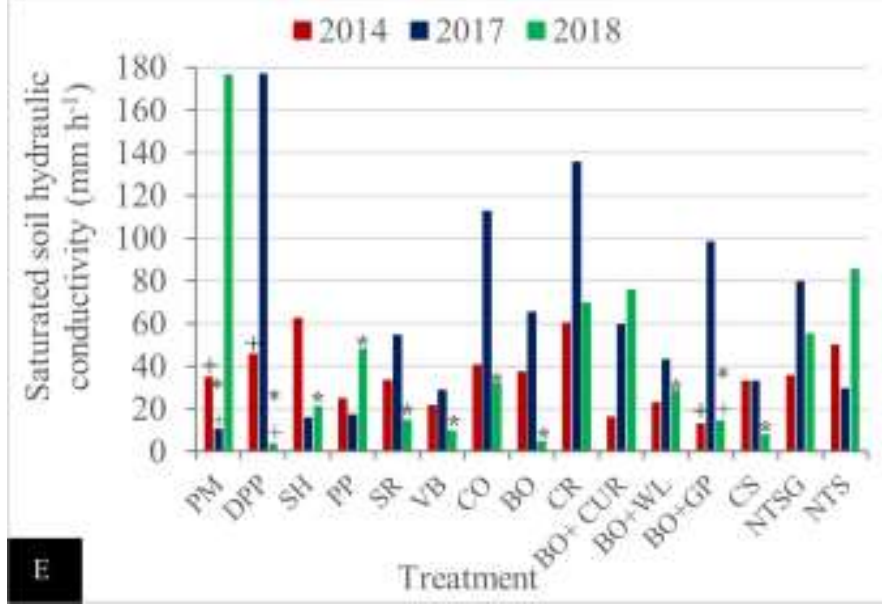

Source: Authors. 
Figure 7. Mean values of bulk density (A), total porosity (B), microporosity (C), macroporosity (D) and saturated soil hydraulic conductivity (E) in treatments with 12 plant cover species and three management systems, in the 0.2-0.3 m layer. PM = pearl millet; $\mathrm{DPP}=$ dwarf pigeon pea; $\mathrm{SH}=$ sunn hemp; $\mathrm{PP}=$ pigeon pea; $\mathrm{SR}=$ showy rattlebox; $\mathrm{VB}=$ velvet bean; $\mathrm{CO}=$ common oat; $\mathrm{BO}=$ black oat; $\mathrm{CR}=$ Cereal Rye; $\mathrm{BO}+\mathrm{CUR}=$ black oat + cultivated radish; $\mathrm{BO}+\mathrm{WL}=$ black oat + white lupine; $\mathrm{BO}+\mathrm{GP}$ = black oat + garden pea; CS: chiseling system; NTSG: no-tillage system with gypsum; NTS: no-tillage system (control). The mean value is indicated by + when significant differences occurred between the periods and indicated by $*$ when significant differences occurred between the treatments by the Tukey test, at $5 \%$ significance $(* \mathrm{P}<0.05)$.
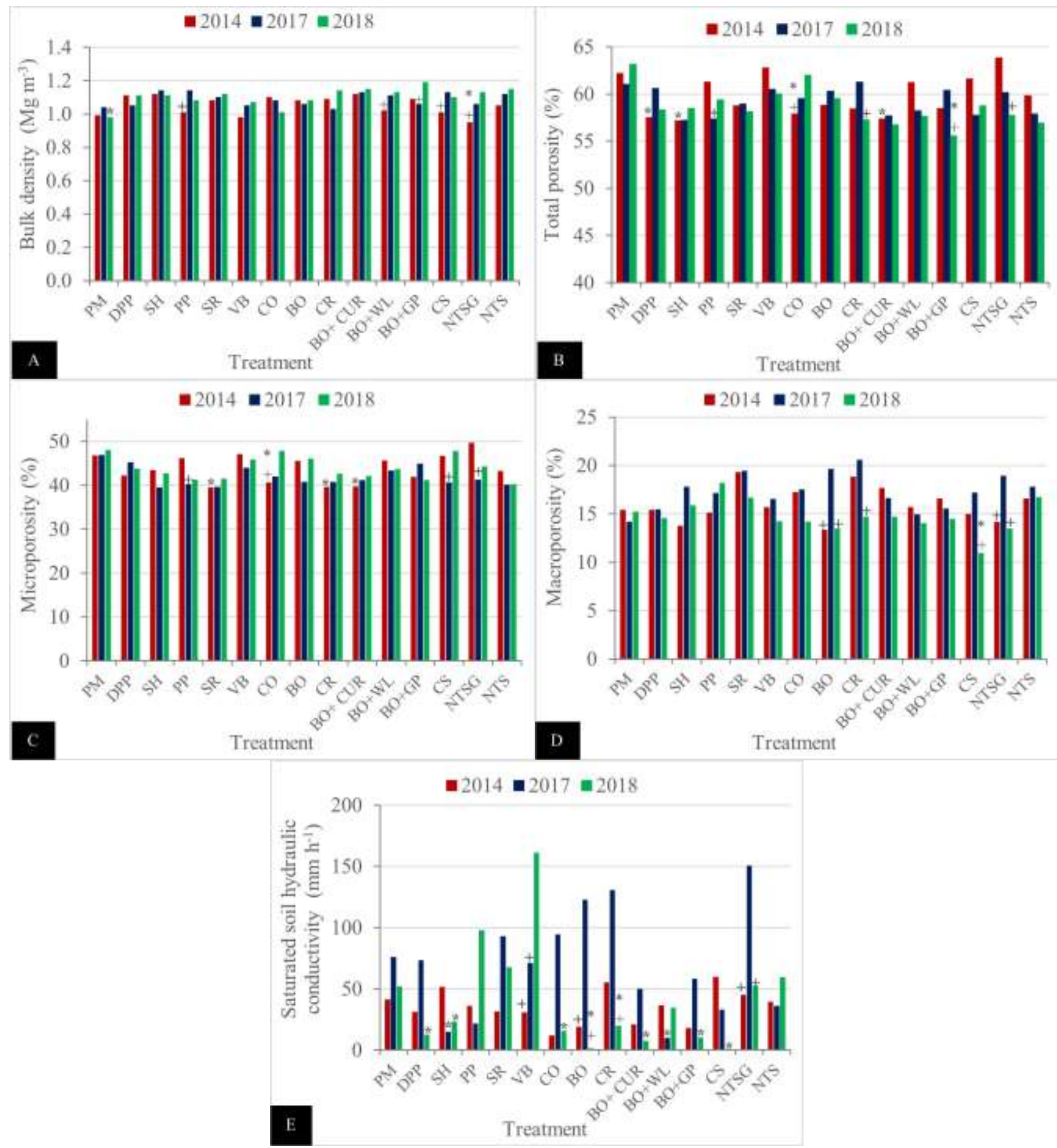

Source: Authors. 
After analyzing only, the three management systems as a function of the physical attributes of the soil, it can be verified that after five months of the scarification operation, the bulk density values did not differ from those obtained prior to the implantation of the experiment in the soil layers, demonstrating that the possible beneficial effects have lasted for a short time. Similarly, six months after the application of gypsum in the soil, no significant differences were observed between treatments.

Similar results were obtained by Tokura et al. (2018), who state that after five months of scarification, the effect is no longer significant. While, eleven months after the application of gypsum there was a slight improvement in bulk density, total porosity, microporosity, macroporosity and saturated soil hydraulic conductivity in the layers of $0-0.10$ and $0.10-0.20 \mathrm{~m}$ of soil (Tokura et al., 2017).

Busscher et al. (2002) state that the scarification effect is temporary and that the scarified soil tends to reconsolidate, returning to its original condition after a short time. Nicoloso et al. (2008) did not observe improvements in soil physical conditions after nine months of mechanical scarification in the 0-0.05 m layer. They also reported that scarification was only efficient when associated with winter cover species.

In the 0.1-0.2 m layer (Figure 6), there was a significant interaction between the periods and evaluated treatments.

For BD and TP, the significant interaction between the periods occurred on the DPP cover $\left(1.05 \mathrm{Mg} \mathrm{m}^{-3}\right.$ and $59.57 \%$, respectively) in the year 2017. In the following year (2018), there was no difference between the treatments.

In Micro, the significant interaction was observed between the periods and treatments, in which the cover that stood out was CO (44.72\%) in the year 2018.

The highest Macro values were obtained on the SR (17.92\%) and CO (18.64\%) covers in 2017, as well as PM $(21.57 \%)$ in 2018.

For the Ksat, the highest values were observed for the coverage of DPP $\left(176.89 \mathrm{~mm} \mathrm{~h}^{-1}\right)$ and BO $+\mathrm{GP}\left(98.28 \mathrm{~mm} \mathrm{~h}^{-1}\right)$ in 2017 and PM $\left(176.56 \mathrm{~mm} \mathrm{~h}^{-1}\right)$ in the year 2018.

The absence of significant effects between treatments can be explained by the values of BD, which were between 0.80 and 1.19 $\mathrm{Mg} \mathrm{m}^{-3}$, in line with the results found by Kiehl (1979), who states that bulk density is considered ideal when it varies from 1.0 to $1.2 \mathrm{Mg} \mathrm{m}^{-3}$, for clayey soils. According to Imhoff et al. (2001), BD is one of the most used physical characteristics as indicators of soil structural quality. On the other hand, values between 1.25 and $1.30 \mathrm{Mg} \mathrm{m}^{-3}$ in very clayey soils are described by Reichert et al. (2003) as critical values and restrictive to root development.

Another factor that should be emphasized is macroporosity. According to Silva and Kato (1997), this parameter is an important factor for the hydraulic conductivity of the saturated soil, as an increase in macroporosity results in an increase in the water infiltration capacity in the soil. Osunbitan et al. (2005) also corroborate this finding, stating that, as the continuity of macroporosity is preserved in the no-tillage system, it contributes to the saturated soil hydraulic conductivity.

Significant interactions were also obtained between the periods and treatments evaluated, in the 0.2-0.3 $\mathrm{m}$ layer (Figure 7).

Between the periods, the lowest $\mathrm{BD}$ value occurred on the $\mathrm{BO}+\mathrm{GP}$ cover $\left(1.06 \mathrm{Mg} \mathrm{m}^{-3}\right)$ in 2017 . Among the treatments, the PM cover $\left(0.98 \mathrm{Mg} \mathrm{m}^{-3}\right)$ presented the lowest value in year 2018.

The interaction between the periods in the TP was observed on the CR (61.29\%) and BO+GP (60.43\%) covers in 2017 and CO $(62.00 \%)$ cover in the year 2018. Among the treatments, the highest TP value was obtained in the PM cover $(63.18 \%)$.

Among the periods, the cover that stood out was CO (47.83\%) and the CS (47.83\%) system over Micro in 2018.

The highest Macro values between the periods were obtained on the BO cover (19.61\%) and CR (20.59\%) and CS $(17.20 \%)$ and NTSG (18.93\%) systems in 2017. Among the treatments, PP cover (18.18\%) in the year 2018 stood out. 
For the Ksat, the highest values between the periods were observed for the BO cover $\left(122.52 \mathrm{~mm} \mathrm{~h}^{-1}\right)$, CR cover $\left(130.58 \mathrm{~mm} \mathrm{~h}^{-1}\right)$ and NTSG system $\left(150.52 \mathrm{~mm} \mathrm{~h}^{-1}\right)$ in the year 2017, and VB $\left(160.89 \mathrm{~mm} \mathrm{~h}^{-1}\right)$ in the year 2018. Among the treatments, the NTSG system and VB cover were the ones that stood out.

These results are in line with the study developed by Silva et al. (2003), who verified that the traffic intensity of the wheels during the whole cycle of the soybean crop altered the compressibility, bulk density, porosity, and saturated soil hydraulic conductivity in a dystrophic Red Latosol in the depths. The first traffic of the wheels initially influences the behavior of the structure in the surface layer, while the subsequent ones affect the deeper layers.

\subsection{Agronomic analysis of soybean}

The valuesof grain yield, oil content, thousand-seed weight, plant height and number of plants per meter of the soybean crop as a function of 12 species of plant cover and three predecessor management systems in the years 2017 and 2018 are shown in Figure 8.

All parameters of the soybean crop showed significant interaction between the evaluated periods.

The 2018 period presented the highest values for grain yield and thousand-seed weight, while the highest oil content, height, and number of plants per meter occurred for the 2017 period.

The mean soybean yield in the $2016 / 17$ and $2017 / 18$ crops was $4,579 \mathrm{~kg} \mathrm{ha}^{-1}$, higher than the mean of the region, which was 3,828 $\mathrm{kg} \mathrm{ha}^{-1}$ in the 2016/2017 crop (Seab, 2017a) and 3,503 $\mathrm{kg} \mathrm{ha}^{-1}$ in the 2017/2018 crop (Conab, 2018). The results of this study are similar to those reported by Bárbaro-Torneli et al. (2017), who obtained grain yield values of 4,416, 4,362 and 4,036 kg ha-1 when evaluating the productive performance of Lança IPRO soybean in three different experimental areas.

Nevertheless, when observing the two crops separately, grain yield in the 2016/2017 crop was lower than in the latter crop, due to the incidence of Asian soybean rust (Phakopsora pachyrhizi) in the experimental area. Fungal disease impaired plant development and had a negative impact on grain yield. In addition, the cold and drier climate that occurred at the time of sowing began, lengthening the crop cycle and delaying the crop (Seab, 2017b). According to Miles et al. (2011), Asian soybean rust has been one of the major diseases limiting soybean production.

In turn, in the 2017/2018 crop, this increase in grain yield may have been due to the favorable climate (Fig. 2) for the development of the crop and the good structural state of the soil.

The same can be observed for the thousand-seed weight, which was higher in the 2017/18 crop. According to Marques et al. (2008), the thousand-seed weight is a variable that can be used to estimate their efficiency during the grain filling process, in addition to expressing indirectly the size of these seeds and their physiological state.

Regarding the oil content of the grains, the values showed an inverse behavior, in which oil content was higher while the grain weight was lower, and vice-versa. The same happened for plant height and number of soybean plants. Sales et al. (2016) state that the filling mechanisms of the grains with respect to the oil content are still incipient, but there is a negative correlation between the protein and oil content, i.e., the higher the protein content, the lower the oil content of the grain.

When evaluating the parameters among treatments, it was observed that plant height was higher on CO residues (1.09 $\mathrm{m})$ and lower in plots with CS $(0.94 \mathrm{~m})$ in the year 2018. 
Figure 8. Mean values of grain yield (A), oil content (B), thousand-seed weight (C), plant height (D) and number of plaints per meter (E) of the soybean crop as a function of 12 plant cover species and three predecessor management systems (mean value of four replicates) in the years 2017 and 2018. $\mathrm{PM}=$ pearl millet; DPP = dwarf pigeon pea; $\mathrm{SH}=$ sunn hemp; $\mathrm{PP}=$ pigeon pea; $\mathrm{SR}=$ showy rattlebox; $\mathrm{VB}=$ velvet bean; $\mathrm{CO}=$ common oat; $\mathrm{BO}=$ black oat; $\mathrm{CR}=$ Cereal $\mathrm{Rye} ; \mathrm{BO}+\mathrm{CUR}=$ black oat + cultivated radish; $\mathrm{BO}+\mathrm{WL}=$ black oat + white lupine; $\mathrm{BO}+\mathrm{GP}=$ black oat + garden pea; CS: chiseling system; NTSG: notillage system with gypsum; NTS: no-tillage system (control). The mean value is indicated by + when significant differences occurred between the periods and indicated by * when significant differences occurred between the treatments by the Tukey test, at $5 \%$ significance $(* \mathrm{P}<0.05)$.
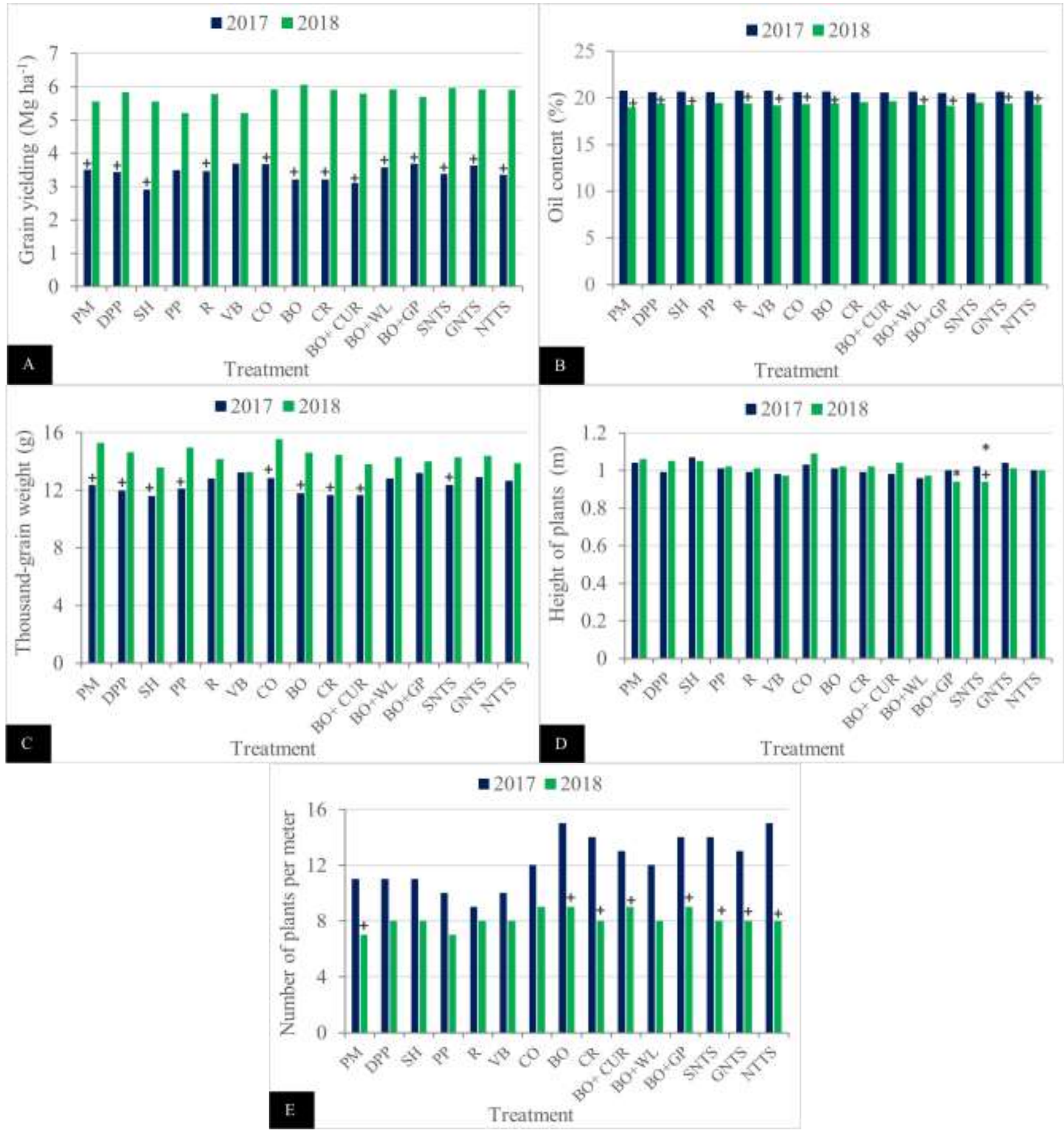

Source: Authors. 
As regards the yield, oil content, thousand-seed-weight and number of plants, there were no significant interactions among the treatments evaluated, and it was not possible to differentiate the plant cover species and management systems that had an influence on the soybean crop.

These results are in line with those obtained by Sanchez et al. (2014), who observed that black oat (Avena strigosa Schreb), ryegrass (Lolium multiflorum Lam.), common vetch (Vicia sativa L.) and radish (Raphanus sativus L.) cover plants showed no changes in soybean yield.

Yusuf et al. (1999) and Khuthcouski et al. (2000) also observed no significant differences when comparing soil and crop management systems on soybean yield.

\section{Conclusion}

Bulk density, total porosity, micro and macroporosity and saturated soil hydraulic conductivity were the variables most influenced by the periods of the year in the three soil layers. Five months after chiseling system, there were no increases in bulk density. Six months after the application of gypsum, there was no differentiation between treatments. The plant height was greater on the crop residues of the oat cover in the year 2018. Grain yield, oil content, thousand-seed weight, plant height and number of plants per meter were influenced by the periods of the year.

\section{Acknowledgments}

The authors would like to thank CAPES, CNPq, FINEP, Araucária Foundation, UNIOESTE, IAPAR and UFPR for supporting the research.

\section{References}

Adetunji, A. T., Ncube, B., Mulidzi, R., \& Lewu, F. B. (2020). Management impact and benefit of cover crops on soil quality: A review. Soil and Tillage Research, 204, 1-11. 10.1016/j.still.2020.104717

Balesdent, J., Chenu, C., \& Balabane, M. (2000). Relationship of soil organic matter dynamics to physical protection and tillage. Soil and Tillage Research, 53, 215-230. 10.1016/S0167-1987(99) 00107-5

Bárbaro-Torneli, I. M., Massaro Sobrinho, R., Libório, P. H. S., Miguel, F. B., Finoto, E. L., Mateus, G. P., Borges, W. L. B., \& Freitas, R. S. (2017). Comparative tests of soybean cultivars in irrigated areas for the region of Guaíra, SP - season 2016/17. Nucleus. Edição especial, 15-26.

Bertol, I., Albuquerque, J. A., Leite, D., Amaral, A. J., \& Zoldan Junior, W. A. (2004). Physical soil properties of conventional tillage and no-tillage, in crop rotation and succession, compared with natural pasture. Revista Brasileira de Ciência do Solo, 28, 155-163. 10.1590/S0100-06832004000 100015

Blanco-Canqui, H., Shapiro, C. A., Wortmann, C. S., Drijber, R. A., Mamo, M., Shaver, T. M., \& Ferguson, R. B. (2013). Soil organic carbon: the value to soil properties. Journal of Soil and Water Conservation, 68, 129A-134A. 10.2489/jswc.68.5.129A

Blanco-Canqui, H., Shaver, T. M., Lindquist, J. L., Shapiro, C. A., Elmore, R. W., Francis, C. A., \& Hergert, G. W. (2015). Cover crops and ecosystem services: insights from studies in temperate soils. Agronomy Journal, 107, 2449-2474. 10.2134/agronj15.0086

Busscher, W. J., Bauer, P. J., \& Frederick, J. R. (2002). Recompaction of a coastal loamy sand after deep tillage as a function of subsequent cumulative rainfall. Soil and Tillage Research, 68, 49-57. 10.1590/S0100-06832008000400037

Caires, E. F., Garbuio, F. J., Alleoni, L. R. F., \& Cambri, M. A. (2006). Surface lime application and black oat cover preceding corn and soybean crops under a no-till system. Revista Brasileira de Ciência do Solo, 30, 87-98. 10.1590/S0100-06832006000100010.

Conab. (2018). Companhia Nacional de Abastecimento. Acompanhamento da safra brasileira. Grãos. v. 5 - safra 2017/2018, n. 8 - oitavo levantamento, maio 2018. Retrieved on March 05, 2018. http://www.agricultura.gov.br/noticias/safra-de-graos-podera-atingir-227-9-milhoes-de-toneladas-em-20172018/AcompanhamentodaSafraBrasileiradeGros4Levantamento20172018.pdf.

Drescher, M. S., Eltz, F. L. F., Denardin, J. E., \& Faganello, A. (2011). Persistence of mechanical interventions effect for soil decompaction in no-tillage systems. Rev. Revista Brasileira de Ciência do Solo, 35, 1713-1722. 10.1590/S0100-06832011000500026.

Drescher, M. S., Reinert, D. J., Denardin, J. E., Gubiani, P. I., Faganello, A., \& Drescher, G. L. (2016). Duration of changes in physical and hydraulic properties of a clayey Oxisol by mechanical chiseling. Pesquisa Agropecuária Brasileira, 51 (2), 159-168. 10.1590/S0100-204X2016000200008

Ferreira, D. F. (2011). Sisvar: A computer statistical analysis system. Ciência e Agrotecnologia, 35, 1039-1042. 10.1590/S1413-70542011000600001 
Giarola, N. F. B., Silva, A. P., Tormena, C. A., Guimarães, R. M. T., \& Ball, B. C. (2013). On the visual evaluation of soil structure: the Brazilian experience in Oxisols under no-tillage. Soil and Tillage Research, 127, 60-64. 10.1016/j.still.2012.03.004

Gimenez, G. S., Almeida Junior, J. H. V., Sambatti, V. C., Nascimento, V., \& Dalazen, G. (2021). Evolution of soil cover and dry shoot phytomass accumulation of autumn/winter cover crops and its effect on the agronomic performance of soybean grown in succession. Research, Society and Development, 10 (4), e3310413797. 10.33448/rsd-v10i4.13797.

Ihmoff, S., Silva, A. P., Dias Junior, M. S., \& Tormena, C. A. (2001). Quantifying critical pressures for plant growth. Revista Brasileira de Ciência do Solo, 25, 11-18. 10.1590/S0100-06832001000100002

Ilek, A., Kucza, J., \& Szostek, M. (2017). The effect of the bulk density and the decomposition index of organic matter on the water storage capacity of the surface layers of forest soils. Geoderma, 285, 27-34. 10.1016/j.geoderma.2016.09.025

Jia, X., Shao, M., Zhu, Y., \& Luo, Y. (2017). Soil moisture decline due to afforestation across the Loess plateau, China. Journal of Hydrology, 546, 113-122. 10.1016/j.jhydrol.2017.01.011

Kiehl, E. J. (1979). Manual de Edafologia. Editora Agronômica Ceres.

Kluthcouski, J., Fancelli, A. L., Dourado-Neto, D., Ribeiro, C. M., \& Ferrero, L. A. (2000). Yield of soybean, corn, common bean and rice under no-tillage management. Scientia Agricola, 57 (1), 97-104. 10.1590/S0103-90162000000100016

Marques, M. C., Rocha, J. E. S., \& Hamawaki, O. T. (2008). Evaluation of the oil content of UFU's soybean cultivars aiming the yield of biodiesel. Horizonte Científico, 2 (1), 1-22.

Mazurana, M., Levien, R., Inda Junior, A. V., Conte, O., Bressani, L. A., \& Müller, J. (2017). Soil susceptibility to compaction under use conditions in southern Brazil. Ciência e Agrotecnologia, 40 (1), 7-25. 10.1590/1413-70542017411027216

Mesquita, M. G. B. F., \& Moraes, S. O. A. (2004). The dependence of the saturated hydraulic conductivity on physical soil properties. Ciência Rural, 34 (3), 963-969. 10.1590/S0103-8478200400030 0052

Miles, M. R., Bonde, M. R., Nester, S. E., Berner, D. K., Frederick, R. D., \& Hartman, G. L. (2011). Characterizing resistance to Phakopsora pachyrhizi in soybean. Plant Disease, 95, 577-581. 10.1094/PDIS-06-10-0450

Nawaz, M. F., Bourrié, G., \& Trolard, F. (2013). Soil compaction impact and modelling. A review. Agronomy for Sustainable Development, 33, 291-309. $10.1007 / \mathrm{s} 13593-011-0071-8$

Nicoloso, R. S., Amado, T. J. C., Schneider, S., Lanzanova, M. E., Girardello, V. C., \& Bragagnolo, J. (2008). Efficiency of mechanical and biological chiseling in the improvement of physical attributes of a heavy clay Oxisol and the increment of soybean yield. Revista Brasileira de Ciência do Solo, 32, 7231734 .

Osunbitan, J. A., Oyedele, D. J., \& Adekalu, K. O. (2005). Tillage effects on bulk density, hydraulic conductivity and strength of a loamy sand soil in southwestern Nigeria. Soil and Tillage Research, 82 (1), 57-64. 10.1016/j.still.2004.05.007

Peel, M. C., Finlayson, B. L., \& McMahon, T. A. (2007). Updated world map of the Köppen-Geiger climate classification. Hydrology and Earth System Sciences, 11, 1633-1644. 10.5194/hess-11-1633-2007

Rabot, E., Wiesmeier, M., Schlüter, S., \& Vogel, H. J. (2018). Soil structure as an indicator of soil functions: A review. Geoderma, 314, 122-137. 10.1016/j.geoderma.2017.11.009

Reinert, D. J., \& Reichert, J. M. (2006). Use of sand column to measure soil water retention - prototypes and test. Ciência Rural, 36 (6), $1931-1935$. $10.1590 / \mathrm{S} 0103-84782006000600044$

Reichert, J. M., Reinert, D. J., \& Braida, J. A. (2003). Qualidade dos solos e sustentabilidade de sistemas agrícolas. Ciência e Ambiente, $27,29-48$.

Saffih-Hdadi, K., Défossez, P., Richard, G., Cui, Y. J., Tang, A. M., \& Chaplain, V. (2009). A method for predicting soil susceptibility to the compaction of surface layers as a function of water content and bulk density. Soil and Tillage Research, 105, 96-103. 10.1016/j.still.2009.05.012

Sales, V. H. G., Peluzio, J. M., Afférri, F. S., Oliveira Junior, W. P., \& Sales, P. V. G. (2016). Oil and protein levels in soybean grain from different parts of the plant. Revista Agroambiente, 10 (1), 22-29. 10.18227/1982-8470ragro.v10i1.2462

Sanchez, E., Maggi, M. F., Genú, A. M., \& Müller, M. M. L. (2014). Propriedades físicas do solo e produtividade de soja em sucessão a plantas de cobertura de inverno. Magistra, 26 (3), 266-275.

Secco, D., Reinert, D. J., Reichert, J. M., \& Silva, V. R. (2009). Crop yield and physical attributes in two oxisols compacted and chiseled. Ciência Rural, 39, 58-64. 10.1590/S0103-84782009000100010

Seab. (2017a). Secretaria da Agricultura e do Abastecimento. Boletins informativos de 2017. Soja - Informe mensal de 28 de abril de 2017. Retrieved on March 08, 2018. http://www.agricultura.pr.gov.br/modules/qas/aviso.php?codigo=5544.

Seab. (2017b). Secretaria da Agricultura e do Abastecimento. Boletins informativos de 2017. Soja - Informe mensal de 14 de março de 2017. Retrieved on March 08, 2018. http://www.agricultura.pr.gov.br/modules/qas/aviso.php?codigo=5473.

Shan, L., Qi-quan, L., Chang-quan, W., Bing, L., Xue-song, G., Yi-ding, L., \& De-yong, W. (2019). Spatial variability of soil bulk density and its controlling factors in an agricultural intensive area of Chengdu plain, southwest China. Journal of Integrative Agriculture, 18 (2), 290-300. 10.1016/S2095$3119(18) 61930-6$ 
Research, Society and Development, v. 10, n. 12, e353101220514, 2021

(CC BY 4.0) | ISSN 2525-3409 | DOI: http://dx.doi.org/10.33448/rsd-v10i12.20514

Silva, C. L., \& Kato, E. (1997). Effect of superficial sealing on the saturated hydraulic conductivity of the surface of a soil under "Cerrado". Pesquisa Agropecuária Brasileira, 32 (2), 213-220.

Silva, R. B., Dias Junior, M. S., Silva, F. A. M., \& Fole, S. M. (2003). The traffic of the tillage tools on the physical, hydric and mechanical properties of a Latosol of the Cerrados. Revista Brasileira de Ciência do Solo, 27 (6), 973-983. 10.1590/S0100-06832003000600002

Silva, F. R., Albuquerque, J. A., \& Costa, A. (2014). Initial growth of the soybean crop in an oxisol with different degrees of compaction. Revista Brasileira de Ciência do Solo, 38 (6), 1731-1739. 10.1590/S0100-06832014000600008

Soil Survey Staff. (2014). Keys to Soil Taxonomy, 12th ed. United States Department of Agriculture - Natural Resources Conservation Service, Washington: DC

Tokura, L. K., Secco, D., Zanão Júnior, L. A., Siqueira, J. A. C., Santos, R. F., Martins, M. F. L., Alovisi, A. M. T., Oliveira, L. C., Hojo, R. H., Pereira, N., Pilatti, M. A., Moreira, M. C. L., Villa, B., \& Schmatz, M. J. (2017). Structuring potential of some cover crops and crambe in Haplortox under no-tillage system. African Journal of Agricultural Research, 12 (24), 2078-2086. 10.5897/AJAR2016.11725

Tokura, L. K., Secco, D., Zanão Júnior, L. A., Siqueira, J. A. C., Souza, S. N. M., Baricatti, R. A., Alovisi, A. M. T., Barison, A., Villa, B., Pilatti, M. A., Rech, K. S., \& Reginatto, R. (2018). Structuring of a Haplortox by soil cover species. Journal of Agricultural Science, 10 (11), 299-310. 10.5539/jas.v10n11p299

Tormena, C. A., Barbosa, M. C., Costa, A. C. S., \& Gonçalves, A. C. A. (2002). Soil bulk density, porosity and resistance to root penetration in an Oxisol managed by different soil tillage systems. Scientia Agricola, 59 (4), 795-801. 10.1590/S0103-90162002000400026

Yusuf, R. I., Siemens, J. C., \& Bullock, D. G. (1999). Growth analysis of soybean under no-tillage and conventional tillage systems. Agronomy Journal, 91 (6), 928-933. 